\title{
Acute liver damage and ecstasy ingestion
}

\author{
A J Ellis, J A Wendon, B Portmann, Roger Williams
}

\begin{abstract}
Eight cases of ecstasy related acute liver damage referred to a specialised liver unit are described. Two patients presented after collapse within six hours of ecstasy ingestion with hyperthermia, hypotension, fitting, and subsequently disseminated intravascular coagulation with rhabdomyolysis together with biochemical evidence of severe hepatic damage. One patient recovered and the other with evidence of hyperacute liver failure was transplanted but subsequently died, histological examination showing widespread microvesicular fatty change. Four patients presented with acute liver failure without hyperthermia. All four fulfilled criteria for transplantation, one patient survived after transplantation, one died before a donor organ became available, and two died within one month posttransplantation of overwhelming sepsis. Histological examination showed submassive lobular collapse. Two patients presented with abdominal pain and jaundice and recovered over a period of three weeks; histological examination showed a lobular hepatitis with cholestasis. Patients developing jaundice or with evidence of hepatic failure particularly encephalopathy and prolongation of the international normalised ratio, or both, whether or not preceded by hyperthermia, should be referred to a specialised liver unit as liver transplantation probably provides the only chance of recovery.

(Gut 1996; 38: 454-458)
\end{abstract}

Keywords: ecstasy, acute liver failure, transplantation, hepatitis, 3,4, methylenedioxymethamphetamine, MDMA.
The social use of 3,4 methyldioxymethamphetamine (MDMA), otherwise known as 'ecstasy', and other drugs with similar effects such as 3,4-methylenedioxyamphetamine (MDA) and 3,4-methylenedioxyethamphetamine (MDEA) is widespread in the United Kingdom and Europe. Ecstasy is taken at 'rave-parties' for its amphetamine-like stimulatory effect allowing users to dance for prolonged periods with increased energy and reduced awareness of fatigue. Publications to date have brought attention to patients collapsing with hyperthermia complicated with disseminated intravascular coagulation and rhabdomyolysis. ${ }^{12}$ Other complications reported include cerebral haemorrhage, hyponatraemia, and cardiac arrhythmias. ${ }^{3-5}$ Seven cases of ecstasy related hepatotoxicity were reported in a study of telephone referrals to The National Poisons Information Service, two of which were subsequently described in more detail in correspondence columns as single cases with liver dysfunction. ${ }^{6-8} \mathrm{Six}$ further cases have been described as single case reports $^{9-12}$ making 13 possible cases in total (Table).

This paper describes eight patients referred to a single centre with evidence of acute liver damage temporally related to the ingestion of ecstasy, two cases presenting with hyperthermia and six with an acute hepatitic illness. Five patients developed encephalopathy and severe coagulopathy sufficient to merit listing for transplantation.

\section{Case histories}

Case 1

A 21 year old woman collapsed after a convulsion having taken both ecstasy and LSD at a party six hours earlier. On admission she was

\begin{tabular}{|c|c|c|c|c|c|c|c|c|c|c|c|c|c|}
\hline $\begin{array}{l}\text { Case } \\
\text { no } \\
\text { (ref) }\end{array}$ & Age & Sex & $\begin{array}{l}\text { Clinical } \\
\text { course }\end{array}$ & Hepatomegaly & Bilirubin & $\begin{array}{l}A S T \\
(\mu \mathrm{mol} /)\end{array}$ & $\begin{array}{l}\text { Alkaline } \\
\text { phosphatase } \\
\text { (IUn) }\end{array}$ & $\begin{array}{l}G G T \\
(I U /)\end{array}$ & $\begin{array}{l}I N R \\
(I U / l)\end{array}$ & $\begin{array}{l}A P T T \\
\text { (secs) }\end{array}$ & $\begin{array}{l}\text { Last ecstasy } \\
\text { use (days) }\end{array}$ & $\begin{array}{l}\text { Time to } \\
\text { resolution of } \\
\text { LFTs (days) }\end{array}$ & Outcome \\
\hline $\begin{array}{l}1^{7} \\
2^{8}\end{array}$ & $\begin{array}{l}27 \\
20\end{array}$ & $\begin{array}{l}\mathrm{F} \\
\mathrm{M}\end{array}$ & $\begin{array}{l}\text { Hepatitis } \\
\text { Hepatitis }\end{array}$ & $\begin{array}{l}3 \mathrm{~cm} \\
\text { None }\end{array}$ & $\begin{array}{l}471 \\
131 \\
(\max 330)\end{array}$ & $\begin{array}{l}1717 \\
2050\end{array}$ & $\begin{array}{l}439 \\
201\end{array}$ & 50 & $\begin{array}{l}\mathrm{N} \\
1.5\end{array}$ & & $\begin{array}{r}10 \\
1\end{array}$ & 21 & $\begin{array}{l}\text { Survived } \\
\text { Survived }\end{array}$ \\
\hline $3^{9}$ & 32 & $\mathrm{~F}$ & Hyperthermia & None & $\begin{array}{l}6 \\
(\max 130)\end{array}$ & 1820 & 107 & & PT $37 \cdot 9$ & & 28 & 28 & Survived \\
\hline $\begin{array}{l}4^{10} \\
5^{6}\end{array}$ & $\begin{array}{l}23 \\
29\end{array}$ & $\begin{array}{l}M \\
M\end{array}$ & $\begin{array}{l}\text { Hyperthermia } \\
\text { Hepatitis }\end{array}$ & & $\begin{array}{l}77 \\
\text { 'Jaundiced' }\end{array}$ & 2659 & & & $3 \cdot 6$ & $>115$ & 1 & $>90$ & $\begin{array}{l}\text { Survived } \\
\text { Survived }\end{array}$ \\
\hline $6^{6}$ & 19 & $M$ & Hepatitis & & 170 & 1509 & 369 & 103 & & & 21 & $>14$ & Survived \\
\hline $7^{6}$ & 19 & $\mathbf{M}$ & $\begin{array}{l}\text { Acute liver } \\
\text { failure }\end{array}$ & & 400 & & & & & & & Liver transplant & Survived \\
\hline $\begin{array}{l}8^{6} \\
9^{6}\end{array}$ & $\begin{array}{l}20 \\
19\end{array}$ & $\begin{array}{l}\mathbf{M} \\
\mathbf{M}\end{array}$ & $\begin{array}{l}\text { Hepatitis } \\
\text { Hepatitis }\end{array}$ & Yes & $\begin{array}{r}40 \\
181\end{array}$ & 659 & 276 & & & & $\begin{array}{l}\text { Regular use } \\
\text { Regular use }\end{array}$ & 'Slow resolution' & $\begin{array}{l}\text { Survived } \\
\text { Survived }\end{array}$ \\
\hline $10^{11}$ & 18 & $\mathrm{~F}$ & $\begin{array}{l}\text { Acute liver } \\
\text { failure }\end{array}$ & No & 480 & 1025 & 30 & 208 & $2 \cdot 7$ & & Regular use & $>50$ & Survived \\
\hline $11^{12}$ & 24 & M & Hepatitis & No & 346 & 950 & 251 & & & & Single exposure & & \\
\hline $12^{12}$ & 22 & $\mathbf{M}$ & Hepatitis & Yes & 137 & 748 & 216 & & & & Single exposure & & \\
\hline
\end{tabular}


deeply unconscious with sluggish and dilated pupils, hypertonic limbs, and no response to pain. Axillary temperature was $41^{\circ} \mathrm{C}$, blood pressure $170 / 100 \mathrm{~mm} \mathrm{Hg}$, and pulse 180 . Blood investigations showed a creatine kinase $4710 \mathrm{IU} / 1, \mathrm{pH} 7 \cdot 27$, arterial bicarbonate $\left(\mathrm{HCO}_{3}\right) 15$, bilirubin $25 \mu \mathrm{mol} / \mathrm{l}$, aspartate aminotransaminase (AST) $3940 \mathrm{IU} /$, alkaline phosphatase $38 \mathrm{IU} / 1, \gamma$-glutamyltransferase (GGT) 62 IU/1. Further convulsions necessitated ventilation, paralysis, and sedation. Computed tomography showed diffuse brain swelling and within 24 hours she developed a severe coagulopathy with an international normalised ratio (INR) $>15$, thrombin time 86 seconds (control 17 seconds), and fibrin degradation products of $2 \mu \mathrm{mol} / \mathrm{l}(\mathrm{N}=<0.5 \mu \mathrm{mol} / \mathrm{l})$ consistent with disseminated intravascular coagulation. Continuous veno-venous haemodiafiltration was started for developing renal failure. Cardiac output rose to $18 \mathrm{l} / \mathrm{min}$ and despite use of fresh frozen plasma and cryoprecipitate, the INR remained grossly prolonged at $8 \cdot 4$. Toxicology showed serum MDMA $0.11 \mathrm{mg} / \mathrm{l}$, urine MDMA $0.04 \mathrm{mg} / 1$.

A diagnosis of hyperacute liver failure was made with criteria for transplantation fulfilled, and a donor organ became available on the fourth day of admission. Postoperatively cardiovascular stability improved and graft function was good but she remained feverish. Despite treatment with broad spectrum antibiotics and systemic antifungal treatment she died of sepsis on day 13 post-transplant. Examination of the explanted liver showed a pale liver on cut section with light microscopy showing enlarged and ballooned hepatocytes resulting from microvesicular fatty infiltration. Scattered eosinophilic single cell necrosis was evident with small foci of collapse due to cell drop out. Inflammation was minimal (Fig 1).

\section{Case 2}

An 18 year old girl noted progressive jaundice over a four week period with malaise, pale stools, and dark urine. She took ecstasy on a regular basis and continued to do so after the appearance of jaundice. Blood tests performed by her doctor showed a serum bilirubin of 277 $\mu \mathrm{mol} / 1$ and an AST of $1575 \mathrm{IU} / \mathrm{l}$. Three weeks later she became confused and by this time the serum bilirubin was $452 \mu \mathrm{mol} / 1$, AST 3160 IU/l, and INR 4.0. On arrival she was encephalopathic (grade II) and haemodynamically stable. Renal function was good with a serum creatinine $91 \mu \mathrm{mol} / \mathrm{l}$, urine output $>50$ $\mathrm{ml} / \mathrm{h}$. Her encephalopathy worsened within 24 hours necessitating paralysis, ventilation, and sedation. Repeat liver blood tests showed albu$\min 34 \mathrm{~g} / \mathrm{dl}$, bilirubin $397 \mu \mathrm{mol} / \mathrm{l}$, AST 974 IU/1, alkaline phosphatase 235 IU/l, GGT 71 IU/l, and an INR of 4. Serological tests excluded known hepatotropic viruses including hepatitis C. Abdominal ultrasound showed a small liver of normal reflectivity. A diagnosis of ecstasy induced acute liver failure was made and she was listed for urgent transplantation. Her INR became more prolonged $(>15)$ and she developed signs of raised intracranial

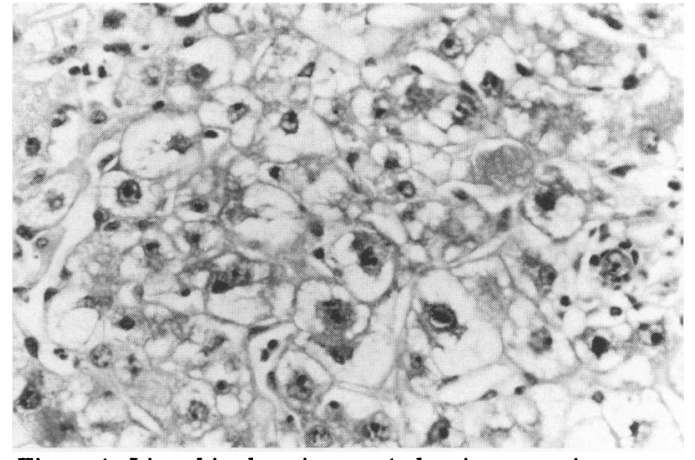

Figure 1: Liver histology in case 1 showing extensive ballooning and cytoplasmic vacuolation of hepatocytes and frequent mitoses in the absence of significant inflammation.

pressure. Despite treatment with broad spectrum antibiotics and intravenous antifungal agents she became profoundly septic with a cardiac output of $18 \mathrm{l} / \mathrm{min}$ and died before a donor organ became available.

\section{Case 3}

A 36 year old woman presented to hospital with a six day illness characterised by nausea and lower back pain with vomiting and the development of jaundice. Ten days before this illness she had taken a single capsule of ecstasy. She was admitted to the local hospital and after 10 days developed encephalopathy and was transferred to King's College Hospital. On admission ascites was detectable clinically and investigations showed a white cell count $11.7 \times 10^{9} / 1$, INR 6.5 , urea $7.4 \mathrm{mmol} / 1$, creatinine $163 \mu \mathrm{mol} / \mathrm{l}$, amylase $23 \mathrm{IU} / \mathrm{l}$, serum albumin $37 \mathrm{~g} / \mathrm{dl}$, bilirubin $406 \mu \mathrm{mol} / \mathrm{l}$, AST 828 IU/l, alkaline phosphatase $90 \mathrm{IU} / 1$, and GGT $78 \mathrm{IU} / \mathrm{l}$. Abdominal ultrasound was unremarkable and serological tests excluded known hepatotropic viruses including hepatitis $\mathrm{C}$. She was ventilated and with criteria for liver transplantation fulfilled was listed for urgent orthotopic liver transplantation, which was carried out on day 5 after admission. After surgery she developed fluctuating increases of AST (119-820 IU/1). Rejection was excluded by liver biopsy and there were no features of graft reinfection with virus. Angiography showed patent recipient vessels. Despite appropriate antibiotics she continued to deteriorate and died 25 days post-transplantation of overwhelming sepsis. Histological examination of the explanted liver showed widespread cell loss with islands of surviving cells composed of vesiculated or ballooned hepatocytes (Fig 2).

\section{Case 4}

A 21 year old woman with a four month history of taking up to five ecstasy tablets at weekends was admitted with right upper quadrant pain. Six weeks before admission she experienced a 'flu-like' illness followed by general malaise and continuous pain associated with vomiting and pale stools. On admission she was not encephalopathic and examination was unremarkable apart from abdominal tenderness. Initial investigations showed a white cell count of $5.7 \times 10^{9} / 1$, INR 0.93 , creatinine $63 \mu \mathrm{mol} / 1$, 


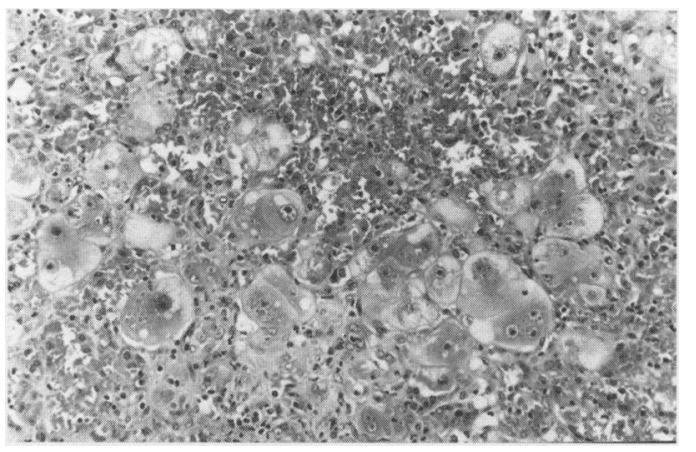

Figure 2: Liver histology in case 3 with confluent parenchymal collapse with clusters of surviving, considerably enlarged hepatocytes.

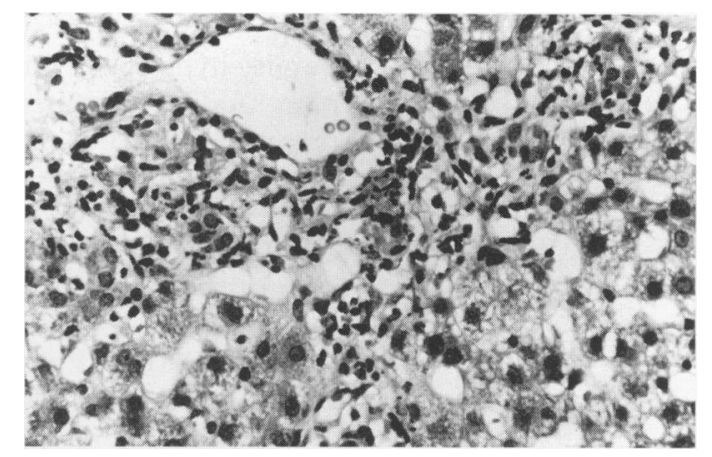

Figure 3: Acute hepatitis in case 6 with the portal area being infiltrated by lymphocytes, neutrophils, and eosinophils.

platelet count increased from 37 to $219 \times 10^{9}$. Serum bilirubin peaked at $287 \mu \mathrm{mol} / 1$ on day 3 . Having required ventilation for six days he was discharged home on day 15 , the serum bilirubin having fallen to $56 \mu \mathrm{mol} / \mathrm{l}$. Liver Unit, King's College Hospital for further investigations and over a two week period as an inpatient her AST settled and she was discharged well. Serological tests excluded known hepatotropic viruses including hepatitis C. Liver biopsy showed a lobular hepatitis with scattered single cell necrosis, acidophilic bodies, and sparse mixed inflammatory cells and occasional pigmented macrophages. The portal tracts appeared lightly infiltrated by mixed inflammatory cells including eosinophils with mild cell spill over at the margin.

\section{Case 5}

A 19 year old man, a regular user of ecstasy, was found unconscious at a party having taken three tablets. No fitting was witnessed. On arrival to his local hospital he was hyperthermic $\left(42^{\circ} \mathrm{C}\right)$, unresponsive (tolerating an airway), and hypotensive with a systolic blood pressure of $90 \mathrm{~mm} \mathrm{Hg}$. He required ventilation and aggressive rehydration with administration of dantrolene (total dose $3 \mathrm{mg} / \mathrm{kg}$ bodyweight over two hours) to reduce body temperature. Investigations showed a white cell count $14 \cdot 8 \times 10^{9} /$, platelets $130 \times 10^{9} / 1$, prothrombin time 24 seconds (control 20 seconds), urea $5 \cdot 2$ $\mathrm{mmol} / \mathrm{l}$, creatinine $175 \mu \mathrm{mol} / \mathrm{l}$, bilirubin 120 $\mu \mathrm{mol} / \mathrm{l}$, AST $80 \mathrm{IU} / \mathrm{l}$, creatinine kinase 22918 IU/1. Toxicological tests on serum showed MDMA $0.38 \mathrm{mg} / \mathrm{l}$, MDA $0.03 \mathrm{mg} / \mathrm{l}$. Twelve hours later a repeat coagulation screen showed an activated partial thromboplastin time of $>120$ seconds (control 35 seconds), prothrombin time $>120$ seconds (control 17 seconds), platelets $38 \times 10^{9} / 1$. Serum AST had risen to $>5000$ IU/1. A diagnosis of disseminated intravascular coagulation and hypoxic/heat induced acute liver damage was made, and he was transferred to King's College Hospital. After admission fluid balance was optimised and urine output maintained at $>100 \mathrm{ml} / \mathrm{h}$ with crystalloid and $\mathrm{NaHCO}_{3}(1 \cdot 4 \%)$ to reduce the risk of renal failure secondary to myoglobinuria. $\mathrm{He}$ remained ventilated for six days with initially signs of fitting and during this time his coagulopathy normalised (INR fell from 5 to $1 \cdot 1$ ),

\section{Case 6}

A 22 year old man presented to his local hospital with a seven day history of malaise, nausea, pale stools, and dark urine and was immediately referred to King's College Hospital. He was a regular user of ecstasy and amphetamine up to the appearance of jaundice. On arrival investigations showed a white cell count of $7 \cdot 8 \times 10^{9} / 1$, INR $1 \cdot 1$, creatinine $99 \mu \mathrm{mol} / 1$, albumin $51 \mathrm{~g} / \mathrm{l}$, bilirubin 311 $\mu \mathrm{mol} / \mathrm{l}$, alkaline phosphatase $173 \mathrm{IU} / \mathrm{l}, \mathrm{AST}$ $1191 \mathrm{IU} / 1$, and GGT $169 \mathrm{IU} / \mathrm{l}$. Over a three day period he required $10 \%$ dextrose to maintain his blood sugar. All known causes of acute hepatitis were excluded and an ultrasound was unremarkable. Liver biopsy showed ballooning of hepatocytes and some acidophilic bodies. Both the sinusoids and portal tracts showed mild to moderate inflammatory infiltrates consisting of lymphocytes, neutrophils, and eosinophils. Cholestasis was evident and overall findings were consistent with a drug related hepatitis (Fig 3).

\section{Case 7}

A 22 year old woman with a six month history of ecstasy use was admitted to her local hospital with a three week history of worsening jaundice associated with nausea and vomiting. Initial investigations showed a serum bilirubin of $129 \mu \mathrm{mol} / 1$ and an INR of 2 . Two weeks later on referral to King's College Hospital her bilirubin had risen to $343 \mu \mathrm{mol} / 1$ and the INR had become more prolonged to 2.9 in association with grade II encephalopathy. With worsening encephalopathy, an INR of $4 \cdot 1$ and her general condition but with the possibility of native liver regeneration, it was decided to proceed to an auxiliary left partial orthotopic transplant. In this procedure the left lateral lobe from the donor organ is implanted in a normal anatomical position following excision of the native left lobe. Her initial postoperative recovery was good but she developed worsening sepsis and died 30 days post-transplant. Histological samples from the excised left lobe 
showed extensive collapse with small areas of regeneration. Biopsy specimens taken in the postoperative period from both donor and native livers showed severe cholestasis compatible with sepsis.

\section{Case 8}

A 24 year old woman presented to casualty in grade III encephalopathy having recently arrived in England after a two month holiday in the Caribbean. She had been seen one week earlier at a local hospital with a non-specific illness and jaundice. There was no hepatosplenomegaly and investigations showed a white cell count of $18 \times 10^{9} / 1, \mathrm{INR}>15$, urea $0.5 \mathrm{mmol} / \mathrm{l}$, creatinine $52 \mu \mathrm{mol} / \mathrm{l}$, glucose 1.2 $\mathrm{mmol} / \mathrm{l}$, albumin $37 \mathrm{~g} / \mathrm{l}$, bilirubin $407 \mu \mathrm{mol} / \mathrm{l}$, alkaline phosphatase $295 \mathrm{IU} / \mathrm{l}, \mathrm{AST} 721 \mathrm{IU} / \mathrm{l}$, GGT 123 IU/1. Fulfilling criteria for transplantation she was placed on the urgent list and a liver became available after 48 hours. Because of a mismatch in size between donor and recipient she received a reduced graft. In the postoperative phase there were no episodes of rejection and she was discharged home well after five weeks. All tests for known causes of acute liver failure were negative and in a subsequent outpatient visit she admitted to having taken two to four tablets of ecstasy in the six weeks prior to her admission. Histological examination showed a small shrunken liver with diffusely collapsed parenchyma. Complete cell drop out was evident with a widespread mixed cell infiltrate, denser in the periportal areas. The findings were consistent with drug or viral induced fulminant hepatitis.

\section{Discussion}

Referrals to our unit with acute liver failure and a history of ecstasy use are increasing. Five cases were referred in 1994 and 1993 with prior to that only single cases in 1989 and 1991 respectively. Ecstasy was the sole agent that could be incriminated in causing the liver damage in eight patients, the other four having also taken a paracetamol overdose with a clinical picture and biochemical changes appropriate to paracetamol ingestion. Of the eight cases with ecstasy as the sole aetiological agent, two had presented with hyperthermia, hypotension, and collapse, four with evidence of acute liver failure without preceding hyperthermia, and two with a less severe hepatitis. On the basis of the patterns of liver damage described, the 13 cases previously reported can be classified similarly with two cases of hyperthermia with liver injury, ${ }^{910}$ two reports of acute liver failure without hyperthermia, ${ }^{6} 11$ and nine cases of apparent drug related hepatitis. ${ }^{6-8} 12$

The clinical features of those cases presenting with hyperthermia are similar to those previously reported in heatstroke, namely hypotension, coagulopathy, renal impairment, and evidence of severe liver injury. ${ }^{13-15}$ Ecstasy users may be at an increased risk of heatstroke because of the direct effect of MDMA on thermoregulation via central serotinergic nerve terminals in addition to high exercise levels, inadequate fluid replacement, and the high ambient temperatures often found at 'raves'. ${ }^{1617}$ Clinical features include cerebral oedema, hypotension, and tissue hypoxia with impaired myocardial contractility secondary to thermal injury, as are seen in acute liver failure. The coagulopathy arises from a combination of hepatic necrosis, endothelial cell damage, and thermal inactivation of clotting factors, platelets, and megakaryocytes.

Survival in patients with heatstroke presenting with a core temperature above $42^{\circ} \mathrm{C}$ is poor $^{2} 18$ and severe hepatic necrosis has been reported in such patients. ${ }^{19} 20$ Patients developing acute liver failure may benefit from transplantation but identification of which cases should be selected is complicated by the overlap between the clinical and biochemical changes in heatstroke and those of acute liver failure. We have considered as possible candidates patients with a core temperature of $>41{ }^{\circ} \mathrm{C}$ along with biochemical changes compatible with the worst prognosis after paracetamol overdose, namely systemic acidosis $(\mathrm{pH}<7 \cdot 3$ ) or renal failure (serum creatinine $>300 \mu \mathrm{mol} / \mathrm{l}$ ), grade III encephalopathy and an INR $>7 .{ }^{21}$ In the only other case report of liver transplantation after heatstroke injury, the patient died after 41 days. ${ }^{22}$ The histological findings of diffuse microvesicular fatty infiltration in case 1, although consistent with a mitochondrial defect (such as in Reye's syndrome), have also been reported in young military recruits with fatal heatstroke. ${ }^{23}$ Whether ecstasy is directly hepatotoxic in these cases or results in liver injury over and above that resulting from the hyperthermia is difficult to determine.

Of the remaining six cases, four had severe liver damage progressing to acute liver failure in the absence of a hyperthermic episode. All other causes of acute liver failure were excluded including hepatitis A, B, C, E, herpes viruses, autoimmune disease, Wilsons's disease, and other potentially hepatotoxic drugs. The illness was characterised by malaise, nausea and vomiting, hyperbilirubinaemia, and progressive coagulopathy followed by the development of encephalopathy and sepsis. One patient survived after transplantation, one died of cerebral oedema before a donor organ became available, and the other two died as a result of continuing sepsis between three and four weeks post-transplantation. The survival rate after transplantation (one of three, $33 \%$ ) in this group is similar to that of other reported series of drug induced acute liver failure and most probably reflects the duration of illness before transplantation and a combination of poor nutrition and sepsis. The remaining two cases presented with a milder illness consistent with a less severe process of hepatic damage and recovered spontaneously over a period of three weeks without developing severe coagulopathy or encephalopathy. In those cases with acute liver damage without heatstroke, the development of coagulopathy may lead to further deterioration and referral to a centre with facilities for liver 
transplantation should be made earlier rather than later as once encephalopathy has developed, deterioration beyond this is rapid. However, to date there is only one case noted with a successful result after transplantation. ${ }^{6}$

The mechanism of MDMA induced hepatic injury is unclear but a spectrum of severity seems to exist as assessed with histological changes varying from a mild to moderate lobular hepatitis to features of massive hepatic parenchymal collapse with areas of nodular regeneration. The severity of liver damage does not seem to correlate with either the amount or frequency of MDMA ingested suggesting an idiosyncratic type of reaction. Individual susceptibility to MDMA hepatotoxicity is possible as a single case of recurrent hepatitis after exposure has been reported. ${ }^{7}$ Except after an acute collapse with hyperthermia, MDMA will not be detectable in the urine or blood because of the short half life of the drug and the usual interval between ingestion and presentation. It is therefore important to include a comprehensive drug history, both oral and intravenous, in young patients presenting with an unexplained hepatitis and care should be exercised in follow up with the risks of progression to acute liver failure.

1 Chadwick IS, Curry PD, Linsley A, Freemont AJ, Doran B. Ecstasy, 3-4 methylenedioxymethamphetamine (MDMA), a fatality associated with coagulopathy and hyperthermia. $\mathcal{F} R$ Soc Med 1991; 84: 371.

2 Tehan B, Hardern R, Bodenham A. Hyperthermia associated with 3,4-methylenedioxyethamphetamine ('Eve'). Anaesthesia 1993; 48: 507-10.

3 Manchanda S, Connolly MJ. Cerebral infarction in association with Ecstasy abuse. Postgrad Med f 1993; 69: 874-5.

$4 \mathrm{Kessel} \mathrm{B.} \mathrm{Hyponatraemia} \mathrm{after} \mathrm{ingestion} \mathrm{of} \mathrm{ecstasy} \mathrm{[Letter].}$ BMF 1994; 308: 414 .

5 Dowling GP, McDonough E, Bost RO, 'Eve' and 'Ecstasy'.
A report of five deaths associated with the use of MDEA and MDMA. $\mathscr{F} A M A$ 1987; 257: 1615-7.

6 Henry JA, Jeffreys KJ, Dawling S. Toxicity and deaths from 3,4-methylenedioxymethamphetamine ('ecstasy'). Lancet 1992; 340: 384-7.

7 Shearman JD, Chapman RW, Satsangi J, Ryley NG, Weatherhead S. Misuse of ecstasy [Letter]. BMF 1992; 305: 309 .

8 Gorard DA, Davies SE, Clark ML. Misuse of ecstasy [Letter]. BMF 1992; 305: 301.

9 Brown C, Osterloh J. Multiple severe complications from recreational ingestion of MDMA ('Ecstasy') [Letter]. recreational ingestion of

10 Fahal IH, Sallomi DF, Yaqoob M, Bell GM. Acute renal failure after ecstasy. $B M \mathcal{F}$ 1992; 305: 348 .

11 deMan RA, Wilson JH, Tjen HS. Acute liver failure caused by methylenedioxymethamphetamine ('ecstasy'). Ned Tijdschr Geneeskd 1993; 137: 727-9.

12 Dykhuizen RS, Brunt PW, Atkinson P, Simpson JG, Smith GC. Ecstasy induced hepatitis mimicking viral hepatitis. Gut 1995; 36: 939-41.

13 Shibolet S, Coll R, Gilat T, Sohar E. Heatstroke: its clinical picture and mechanism in 36 cases. $Q \mathcal{F}$ Med 1967; 36: 525-48.

14 O'Donnell TF. Acute heatstroke. Epidemiological, biochemical, renal and coagulation studies. $\mathscr{f} A M A$ 1975; 234: 824-8.

15 Olson KR, Benowitz NL. Environmental and drug induced hyperthermia. Pathophysiology, recognition and management. Emerg Med Clin North Am 1984; 2: 459-74.

16 Schmidt CJ, Black CK, Abbate GM, Taylor VL. MDMAinduced hyperthermia and neurotoxicity are independently mediated by 5-HT2 receptors. Brain Res 1990; 529: 85-90.

17 Gordon CJ, Watkinson WP, O'Callaghan JP, Miller DB. Effects of 3,4-methylenedioxymethamphetamine on autonomic thermo-regulatory responses of the rat. Pharmacol Biochem Behav 1991; 38: 339-44.

18 Logan AS, Stickle B, O'Keefe N, Hewitson H. Survival following 'Ecstasy' ingestion with a peak temperature of 42 degrees C [Letter]. Anaesthesia 1993; 48: 1017-8.

$19 \mathrm{Kim}$ RC, Collins GH, Cho C, Ichikawa K, Givelber H. Heatstroke: report on three fatal cases with emphasis on findings in smooth muscle. Pathol Lab Med 1980; 104: 345-59.

20 Fidler S, Fagan EA, Williams R, Dewhurst I, Cory CE. Heatstroke and rhabdomyolysis presenting as fulminant hepatic failure. Postgrad Med F 1988; 64: 157-9.

21 O'Grady JG, Alexander GJ, Hayllar KM, Williams R. Early indicators of prognosis in fulminant hepatic failure. Gastroenterology 1989; 97: 439-45.

22 Hassanein T, Perper JA, Tepperman L, Starzl TE, Van Thiel DH. Liver occurring as a component of exertional heatstroke. Gastroenterology 1991; 100: 1442-7.

23 Rubel LR, Ischak KG. The liver in fatal heat stroke. Liver 1983; 3: 249-60. 